\title{
IMPROVING THE STUDENTS' PRONUNCIATION ABILITY THROUGH NRT (NOTICING-REFORMULATION TASK)
}

\author{
Meningkatkan Kemampuan Pengucapan Siswa Melalui NRT \\ Yasser Mallapiang \\ English Education Department, Faculty of Teacher Training and Education \\ Muhammadiyah University of Makassar
}

\begin{abstract}
This research aimed at explaining the improvement of the students' pronunciation ability in terms of English consonant dealing with fricative and affricative and English vowel dealing with front vowel and central vowel. To explain the improvement, the researcher used a Classroom Action Research (CAR) which was conducted in two cycles in which every cycle consisted of four meetings. The location of this research was taken at the eleventh grade students of SMK Negeri 1 Jeneponto with the number of the subject 28 students with 25 women and 3 men. Instruments are pronunciation/reading test and observation. The findings of the research were students' improvement in English consonant of the English fricative consonant was 2.9 in data source (D-Test), 4.2 in cycle 1 and then, it became 6.4 in cycle 2 whereas in English affricative consonant was 3.0 in data source (D-Test), 4.2 in cycle 1 and then, it became 6.6 in cycle II. The students' pronunciation ability of English front vowel was 3.3 in data source (D-Test), 4.6 in cycle 1 and then, it became 6.7 in cycle 2. English Central Vowel was 3.4 in data source (DTest), 4.7 in cycle 1 and then, it became 6.8 in cycle 2. The students' observation was 50.1 $\%$ in cycle 1 and it became $72.9 \%$ in cycle 2. It means that NRT (Noticing-Reformulation Task)is one of the effective teaching strategies for the eleventh grade students at SMK Negeri 1 Jeneponto to improve their pronunciation ability.
\end{abstract}

Keywords: noticing-reformulation task

English pronunciation is a very essential role in communicating, because when speakers mispronounce some words or phrases, people can be misunderstanding. To reduce it, the teacher must equip the learners with certain degree of accuracy and fluency in understanding, responding, and expressing him self in the language in speech in order the learners communicatively in using the language.

Pronunciation has traditionally been taught with a goal of "speaking like a native speaker," but this is not practical. In fact, it is a recipe for discouragement both teachers and students. This has been referred to as "the perfection trap" (Morley in Gilbert 2008: 36). A more practical approach is to aim for "listenerfriendly pronunciation" (Kjellin in Rachim 2011:1). This aim makes sense to a student who hopes to achieve something through conversations with native speakers, whether in the social or business sense. If the listener finds that it takes 
too much effort to understand, the speaker loses out. Thus, mastering the basics of English communication is sensible. Refinements can come later if the student wants to put more effort and time into learning nuances of spoken English.

As we know, the class-atmosphere is an imoportant thing that proves to be very helpful in pronunciation class, (Syafey in Rahman (2010: 3) and also there are many professional researchers who finally success in finding learning methiod that is not only effective in helping the students in understanding the difficult concept of material, but also it is very useful to promote good cooperation, critical thinking, to stimulate them to help their learning in groups in which each learner is held accountable for his own lerning and is motivated to increase the learning of other, (Olsen and Bagon in Richard and Rodger (2001:192) in Rahmah (2010:3), related to the case, researcher indicates that one of school that owns a name of benchmark school is SMK Neg. 1 Jeneponto that has a good rating to do a research (Diagnostic test and performance rate of the head region 2012) that has successful rate between $65 \%$ and $70 \%$ in pronunciation aspect.

In the last decade, the use of certain technique for recording on a tape/computer has developed rapidly through out the world. According to Smith and Beckmann (2005) state that the technique takes students through a series of steps including listening to and analyzing their own speech according to specific phonetic features and then comparing their pronunciation to that of a model pronunciation of the same text. With respecting to the second/foreign language teaching and learning, NRT (Noticing-Reformulation Task) is outlined here as a generic model of the NRT (Noticing-Reformulation Task), incorporating a few changes made since the original design (Beckmann \& Smith, forthcoming). Nowadays, the NRT (Noticing-Reformulation Task) environment becomes an ideal media for learners to practice interaction. The record tape or computer, accompanying text and recording packages have been used in a number of ways to assist language learning. There are many recordings that we can use in it, but here we model it based on a tape-script recording which is a teacher could provide a model pronunciation for a student's spontaneous text, provided a tape-script is written by either the student or the teacher after the initial recording in reading the short text onto a tape. In a class situation, however, reading a given text seems to 
be the most time-efficient solution. Note that reading skills are assumed, as the task is designed for advanced learners.

\section{1) Definition of NRT (Noticing-Reformulation Task)}

According to Smith and Beckman (2005:1) in the journal of NRT (NoticingReformulation Task) in main idea outline that noticing and reformulation in designing the pronunciation strand of the course, we consultthe current literature on teaching English. Apart from a rather obvious, but nonetheless encouraging idea that overtly teaching pronunciation, especially suprasegmental, is effective in improving pronunciation, two ideas stood out as being effective for teaching other skills to advanced learners, namely noticing and reformulation.

\section{a. Noticing}

Schmidt and Frota (1986:326) state that two kinds of noticing are necessary conditions for acquisition:

1) Learners must attend to linguistic features of the input that they are exposed to, without which input cannot become 'intake'

2) Learners must 'notice the gap' i.e. make comparisons between the current state of their developing linguistic system, available as input

Furthermore, Sharwood Smith (1993:326-327)) states that noticing is customerely promoted through activities and procedures involving input enhancement, whereby targeted features of the input and made salient in order to facilitate their becoming intake.

Thornbury (1997:1) also describes a noticing technique for the teaching of written grammar. In this learners are trained to notice both their own output and native speaker input. He goes on to suggest the comparison of two, and calls this 'noticing the gap.' Therefore, noticing is a process to analyze a case that based on thinking and achievement of a given source. Through that case, it is also an observation by mind or eye or attention, it means that the process of it is the process an observation of the result of mind in relating to an attention of observation in processing it.

\section{b. Reformulation}


Thornbury (1997:1) states that it is described as a correction process whereby a teacher recasts content is written by a student so that the second draft approximates as closely as possible to a target language model. Through the case, it involves two main aspects, they are students and teacher, they are also involved in teaching mainly, in reformulation, it then reverses the orderof traditrional models of instruction, which move from accuracy to fluency as for example, when learners are required to imitate model text (as in a product approach to writing) or to drill pre-selected structures for subsequent use in 'freer practice' activity.

Furthermore, reformulation is consistent with a fluency-to-accuracy, or task based, model of instruction, that is, one that 'encourages learners to make the best use whatever language they have. It assumes that learners will find ways of encoding the meanings they have in order to achieve the outcome, (Willis 1990:128). Once is encoded by the teacher, these meanings are then 're-encoded' or re-formulate by the teacher. Derwing,Lynch, and Menim in Improving Pronunciation through Noticing-Reformulation Task Journal (2005:1) also refer the usefullness of a reformulation-type tyechnique in helping learners to correct their own errors in speaking.

\section{c. Task}

Acording to Oxford Learner's Pocket Dictionary (2008:454) states that it is a piece of (hard or unpleasant) work that has to be done. It is given by certain teacher to measure the students' quality, beside that it is one of stimulation to improve how their the result of teaching during teaching-learning process.

Long (1985:89) argues that task is a piece of work undertaken for oneself or for other, freely or for some rewards thus, examples of tasks include painting, a fence, dressing a child, filling out a form, buying a pair of shoes, making an airline reservation, borrowing a library book, taking a driving test, typing a letter, weighing a patient, sorting letters, making a hotel reservation, writing a cheque, finding a street destination and helping someone across a road. In order words, by "task" is meant the hundred and one things people do in everyday life, at work, at play and in between. 
According to Richards, et al (1986:289) states that an activity or action which is carried out as the result of processing or understanding language (i.e. as a response) for example, drawing a map while listening to an instruction and performing a command may be referred to as task usually requires the teacher to specify what will be regarded as successful completion of the task in language teaching is said to make language teaching more communicative since it provides a purpose for a classroom activity which goes beyond the practice of language for its own sake.

NRT (Noticing-Reformulation Task ) is one of technique that used in teaching pronunciation to know interelation between text and recording is given in which this technique describes imitation of stimulus of text, this technique can be used as an assesment technique, as it was originally design, provided the students have already learned the relevant phonological or phonetic theory used for the analyses the modelling and speech of noticing. The technique can also be adapted for the use as a teaching tool during a lesson. Here are how it works:

a. Setting a context - students are shown a stimulus (such as a photo, video clip, item) which acts as a context for a short written text which they are given. The text is typically a narative or description of the stimulus.

b. Initial output - learners read the short text onto a tape - it is typically 10-30 seconds long.

c. Noticing own speech - learners listen to their recording and then analyse their pronunciation according to selected phonetic features. A worksheet is provided with targeted questions for students to answer about their pronunciation of certain items in the text.

d. Model input - learners are then given a recording of a model pronunciation of the text

e. Noticing model - learners analyse the model text for target phonetic features, again with a worksheet provided.

f. Noticing the gap - learners compare their own pronunciation with the model pronunciation, using their analyses as a guide.

g. Reformulation - learners practise and prepare for a second recording, aiming to correct any errors they noticed. 
h. Informed output - learners record the text a second time.

i. Reflection - learners compare their first and second recordings and comment on any improvements or continued errors.

\section{METHOD OF THE RESEARCH}

\section{A. Research Design}

In this research, the researcher will use Classroom Action Research (CAR) that will be done through two cycles with four phases, namely: 1) Plan, 2) Action, 3) Observation, and 4) reflection. The researcher describes the cycles through scheme of action research steps and each phase can be explained briefly as follows:

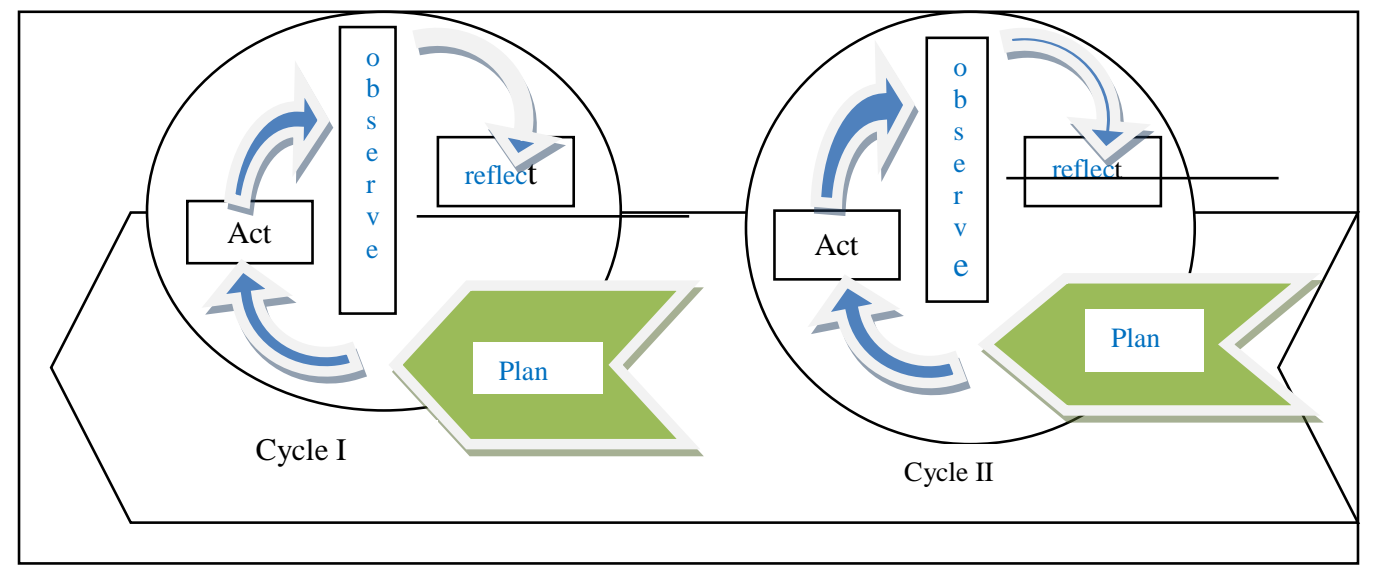

The Cycle of CAR Adaptation from Kemmis (Hopkins in Rachim (2011:27).

1. Schedule

This classroom action research was conducted at SMK Negeri 1 Jeneponto. The subject of this research was the eleventh gradestudents of SMK Negeri 1 Jeneponto. Especially of class XI. Accounting Unggulan in 2013/ 2014 academic year. The schedule conducted in September - November 2014.

2. Cycle

This classroom action research was conducted through two cycles. It means at observing the improving the students' pronunciation ability through NRT (Noticing-Reformulation Task) in the classroom was held in two cycles.

3. Research time 
This research was conducted in September - November 2014 academic year.

This research time determined based on school academic calendar because classroom action research required two cycles.

\section{B. Research Subject}

The research subject of this classroom action research had been done in the eleventh grade students at the Accounting Unggulan Grade during two months 2014-2015 academic year which was the survey of the class consists of 28 students with 25 women and 3 men.

\section{Research Instrument}

There were two instruments used. Firstly, observation sheet aimed to find out the students' data about their presence and activeness in learning process. In observation sheet, the researcher also gave a scoring to analyze the students' participation in the research toward the material and activities in teaching and learning process by checklist. The students' active participation would be described as follows:

Table 1

The Students' Activeness Participation Assessment

\begin{tabular}{|l|l|c|l|}
\hline No. & \multicolumn{1}{|c|}{$\begin{array}{c}\text { The Students' Activeness } \\
\text { Participation }\end{array}$} & Score & \multicolumn{1}{|c|}{ Indicator } \\
\hline 1 & Very Active & 4 & $\begin{array}{l}\text { Students' response to the material very } \\
\text { active }\end{array}$ \\
\hline 2 & Active & 3 & $\begin{array}{l}\text { Students' response to the material } \\
\text { actively }\end{array}$ \\
\hline 3 & Fairly active & 2 & $\begin{array}{l}\text { Students' response to the material just } \\
\text { once or twice. }\end{array}$ \\
\hline 4 & Not active & 1 & $\begin{array}{l}\text { Students just sit down during the } \\
\text { activity without doing something. }\end{array}$ \\
\hline
\end{tabular}

The chart above showed that every students who filled some criterias such as, very active, active, fairly active, and not active. Thus, the score was given to $\mathrm{him} /$ her to determine the student's activation in teaching-learning process through NRT (Noticing-Reformulation Task) in the classroom.

Secondly, reading test aimed to get information about students' pronunciation improvement after teaching and learning process by using NRT (NoticingReformulation Task).

\section{The Procedure of Collecting Data}


In collecting the data, the researcher used two instruments, they were: Observation sheet and Reading test. Observation sheet, the researcher would observe the students' activity in following teaching and learning process in the class to find out the students' data about their presence and activeness in teaching learning process through student's participation sheet during the test in the classroom. Meanwhile, reading test, the researcher would give pronunciation test in reading text form to the students in order to know their improvement. The type of pronunciation reading test which would be used in this research was descriptive reading form. The researcher had divided the students into some groups and asked one of the groups to read the reading text by using pronunciation correctly that had been learned.

In scoring the result of students' test had been evaluated based on one aspect speaking below:

\section{Table 2}

The Assessment of Pronunciation

\begin{tabular}{|l|c|l|}
\hline Classification & Score & \multicolumn{1}{c|}{ Criteria } \\
\hline Excellent & 6 & $\begin{array}{l}\text { Pronunciation is only very slightly influenced by mother } \\
\text { tongue. Two or three grammatical and lexical errors. }\end{array}$ \\
\hline Very Good & 5 & $\begin{array}{l}\text { Pronunciation is lightly influenced by mother tongue. A few } \\
\text { minor grammatical and lexical errors but most utterances are } \\
\text { correct. }\end{array}$ \\
\hline Good & 3 & $\begin{array}{l}\text { Pronunciation is still moderately influenced by mother } \\
\text { tongue but no serious phonological errors. A few } \\
\text { grammatical and lexical errors but only one or two major } \\
\text { error causing confusion. }\end{array}$ \\
\hline Average & 2 & $\begin{array}{l}\text { Pronunciation influenced by the mother tongue but only a } \\
\text { few serious phonological errors. Several grammatical and } \\
\text { lexical errors, some of which cause confusion. }\end{array}$ \\
\hline Poor & 1 & $\begin{array}{l}\text { Pronunciation seriously influenced by mother tongue with } \\
\text { errors causing a breakdown. Many "basic" grammatical and } \\
\text { lexical errors. }\end{array}$ \\
\hline Very poor & $\begin{array}{l}\text { Serious pronunciation errors as well as many "basic" } \\
\text { grammatical and lexical errors. No evidence of having } \\
\text { mastered any of the language skills and areas practiced in } \\
\text { the course. }\end{array}$ \\
\hline
\end{tabular}

(Heaton)

Students' Correct Answer

Score $=\mathrm{x} 10$

Maximum Score (6)

\section{E. Technique of Data Analysis}

The data that had been gotten from cycle I and cycle II were analyzed through following steps: 
1. Calculating the mean score of the students' Pronunciation test by using the following formula:

$$
X=\frac{\sum X}{N}
$$

Where:

$$
\begin{aligned}
& \mathrm{X}=\text { The mean score } \\
& \sum X=\text { The total raw score } \\
& \mathrm{N}=\text { The number of students }
\end{aligned}
$$

2. To classify the students' score, there were seven classifications which were used as followed:

1) Score $8.6-10$ is classified as excellent

2) Score $7.6-8.5$ is classified as very good

3) Score $6.6-7.5$ is classified as good

4) Score $5.6-6.5$ is classified as fair

5) Score $3.6-5.5$ is classified as poor

6) Score $0.0-3.5$ is classified as very poor

3. To calculate the percentage of the students' score and the percentage of students' participation, the researcher used percentage formula.

\section{FINDINGS AND DISCUSSION}

\section{Result of the Students' Improvement in English Consonant}

a. The Rate Percentage of the Students' Pronunciation in English Consonant and Vowel Are Obtained through Reading Test in Cycle I and Cycle II

The implementation of NRT (Noticing-Reformulation Task) in improving the students' pronunciation ability in English consonant is dealing with fricative and affricative. Based on the results of the observation indicates that cycle I some of the students know a little fricative sounds $\left(\theta, \delta, \int\right)$, whereas there are 1 student (3.5\%) got good, although 18 students (64.2\%) got poor and 9 students $(32.1 \%)$ got very poor. In affricative sound showed that 2 students (7.1\%) got good, 3 students (10.7\%) also got fair, 10 students (35.7\%) got poor and 13 students (46.4\%) got very poor. In front vowel case 3 students (10.7\%) got good, 2 students (7.1\%) got fair, 23 students $(82.1 \%)$ got poor, and none of the students got very poor. In central vowel 3 students (10.7\%) got good, 4 students (14.2\%) got fair, 
16 students $(57.1 \%)$ got poor and 5 students (17.8\%) got very poor. The researcher needed to do stabilization in the second cycle especially the students' English fricative consonant. Next, in cycle II it can be improved until there are 2 students $(7.1 \%)$ got very good, 8 students $(28.5 \%)$ got good, 15 students $(53.5 \%)$ got fair, and 3 students (10.7\%) got poor, and there is no students got very poor as like in cycle I.

Based on the results of the observation of affricative consonant and front and central vowel indicate that affricative consonant of cycle II some of the students are still hard to pronounce it, whereas there are 2 students (7.1\%) got very good, 15 students $(53.5 \%)$ got good, 11 students (39.2\%) got fair although no more students got poor. The researcher needed to do stabilization in the second cycle especially the students' English central vowel. Next, in cycle II it can be improved until there are 4 students $(14.2 \%)$ got very good, 11 students $(39.2 \%)$ got good, 13 students (46.6\%) got fair and no more students got poor and even very poor but it is not as significant as like as in cycle I. In front vowel case, it shows that 2 students (7.1\%) got very good, 12 students (42.8\%) got good, 14 students $(50.0 \%)$ got fair, and no more students got poor and very poor.

\section{Graphic 1}

The rate percentage of the students' pronunciation ability of fricative and affricative consonant can be seen in the following table:

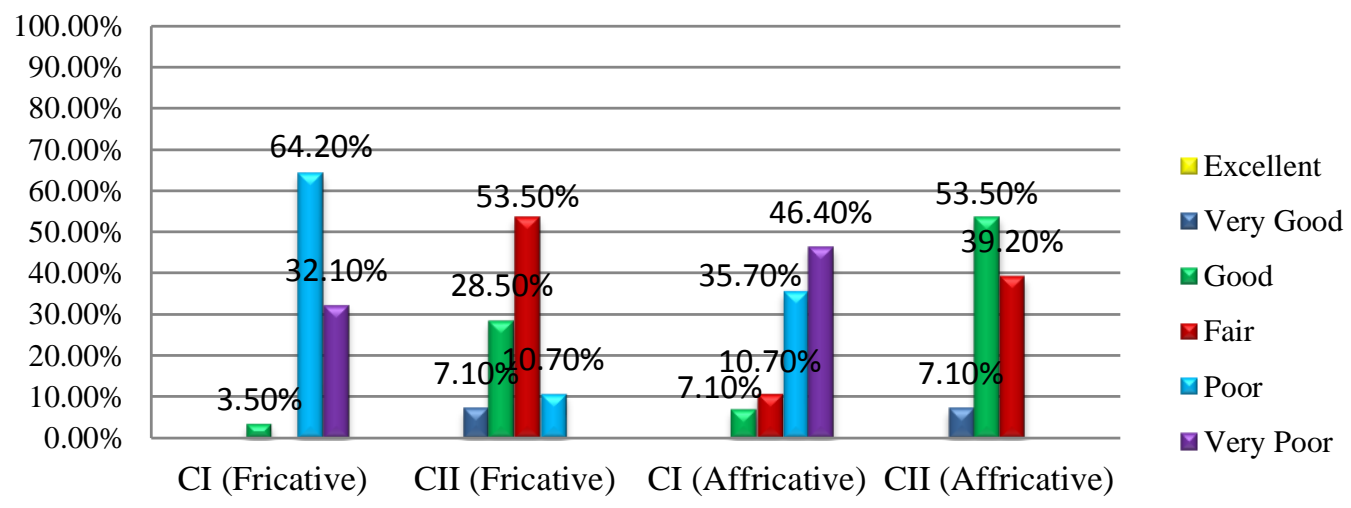




\section{Graphic 2}

The rate percentage of the students' pronunciation ability of front and central vowel can be seen in the following table:

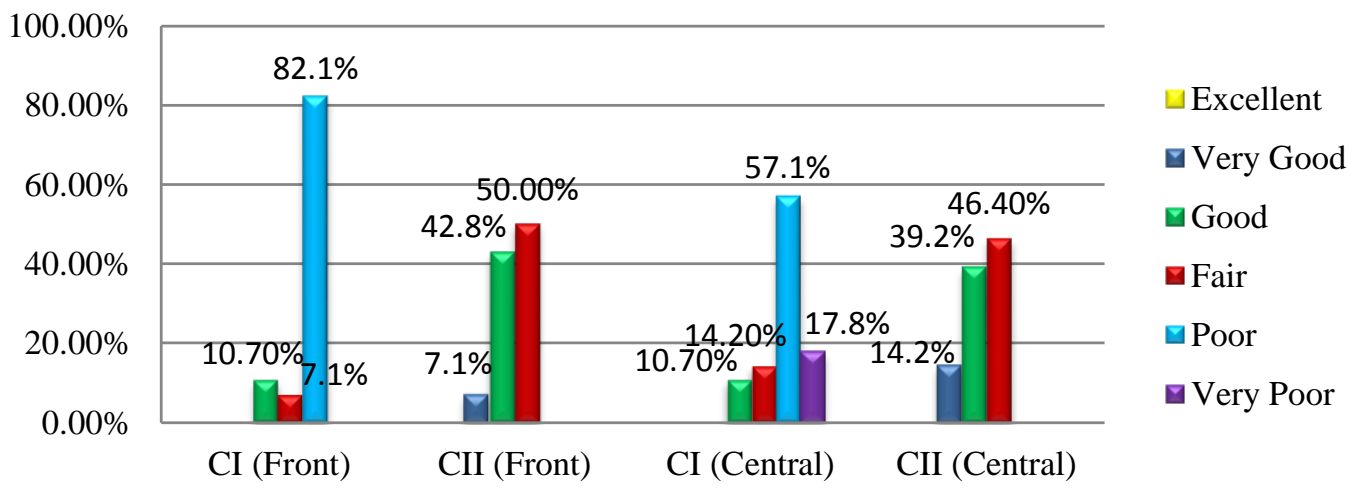

b. The Students' Mean Score of Pronunciation Ability in Data Source (D-Test), Cycle I and Cycle II

Table 1

The Students' Mean Score of English Consonant

\begin{tabular}{|c|c|c|c|c|c|}
\hline \multirow{2}{*}{$\begin{array}{l}\text { Data Source } \\
\text { (D-Test) }\end{array}$} & \multirow{2}{*}{$\begin{array}{c}\text { Data Source } \\
\text { (D-Test) }\end{array}$} & \multicolumn{4}{|c|}{ English Consonant } \\
\hline & & \multicolumn{2}{|c|}{ Fricative } & \multicolumn{2}{|c|}{ Affricative } \\
\hline Fricative & Affricative & $\mathrm{CI}$ & CII & $\mathrm{CI}$ & CII \\
\hline 2.9 & 3.0 & 4,2 & 6.4 & 4.2 & 6,6 \\
\hline
\end{tabular}

The table above shows that there is improvement of the students' pronunciation ability from data source (D-Test) to cycle I and cycle II, where in data source (D-test) the students' mean score achievement in pronunciation ability of fricative and affricative consonant are (2.9) and (3.0), but after implementing NRT (Noticing-Reformulation Task) in cycle I the students' pronunciation ability of fricative and affricative consonant become (4.2) and (4.2). Even though, the movement is not as significant as well. Therefore, the researcher decided to organize cycle II with several re-correcting activities and the result of cycle II are (6.4) and (6.6) are greater than data source (D-Test) and cycle I. 
Graphic 3

The Students' Mean Score Improvement in English Consonant

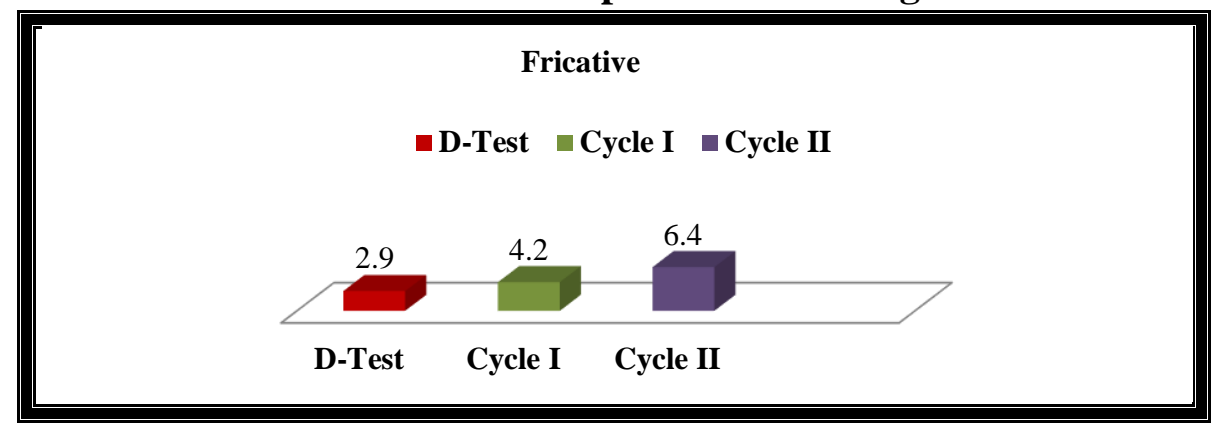

Graphic 4

The Students' Mean Score Improvement in English Consonant

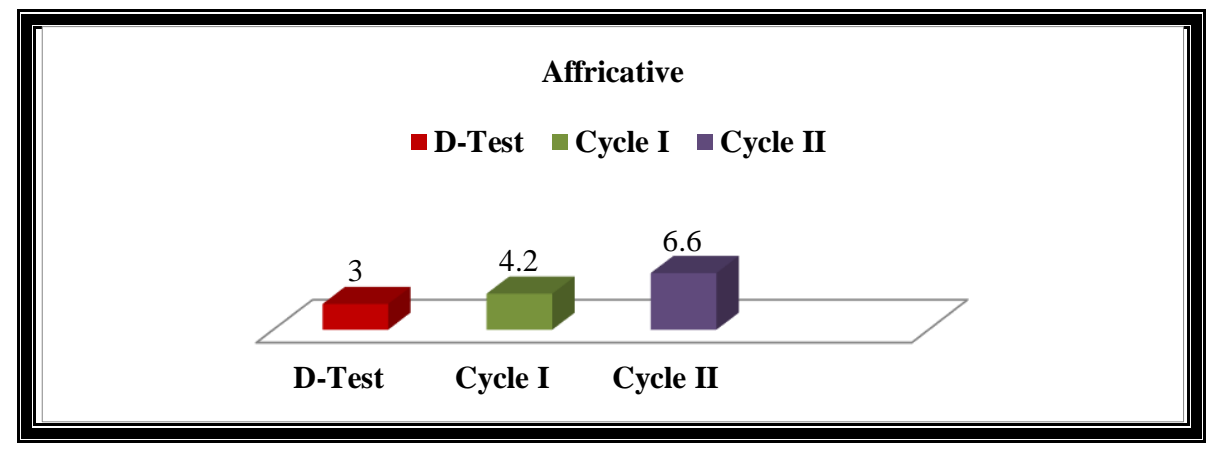

The graphic above shows the improvement of the students' pronunciation ability of English fricative consonant and English affricative consonant in cycle II are higher (6.4) and (6.6) than cycle I (4.2) and also (4.2) whereas data source (DTest) (2.9) and (3.0). It also shows that the result of data source is the lowest ability. After Implementing NRT (Noticing-Reformulation Task) in cycle I and cycle II, there is a significant improvement of the students' pronunciation ability of English fricative consonant and English affricative consonant.

Table 2

The Students' Mean Score of English Vowel

\begin{tabular}{|c|c|c|c|c|c|}
\hline \multirow{3}{*}{$\begin{array}{c}\text { Data Source } \\
\text { (D-Test) }\end{array}$} & \multirow{4}{*}{$\begin{array}{c}\text { Data Source (D-Test) } \\
\text { Central Vowel }\end{array}$} & \multicolumn{4}{|c|}{ English Vowel } \\
\hline & & \multicolumn{2}{|c|}{ Front } & \multicolumn{2}{|c|}{ Central } \\
\hline & & CI & CU & CI & $C H$ \\
\hline Front Vowel & & & & & \\
\hline 3.3 & 3.4 & 4,6 & 6.7 & 4,7 & 6,8 \\
\hline
\end{tabular}


In the table above also shows that the indicators of students' pronunciation ability (D-Test) improve significantly where in data source, the students' English front and central vowel are (3.3) and (3.4), but after implementing NRT (NoticingReformulation Task) in cycle I, the students' achievement in English front and central vowel become (4.6) and (4.7) whereas in cycle II becomes (6.7) and (6.8). The table above also shows that there is a significant improvement of students' pronunciation ability after taking an action in cycle I and cycle II through NRT (Noticing-Reformulation Task). To see clearly the improvement of the students' pronunciation ability of English front vowel and English central vowel, the following graphic is presented as follows:

Graphic 5

The Students' Mean Score Improvement in English Vowel

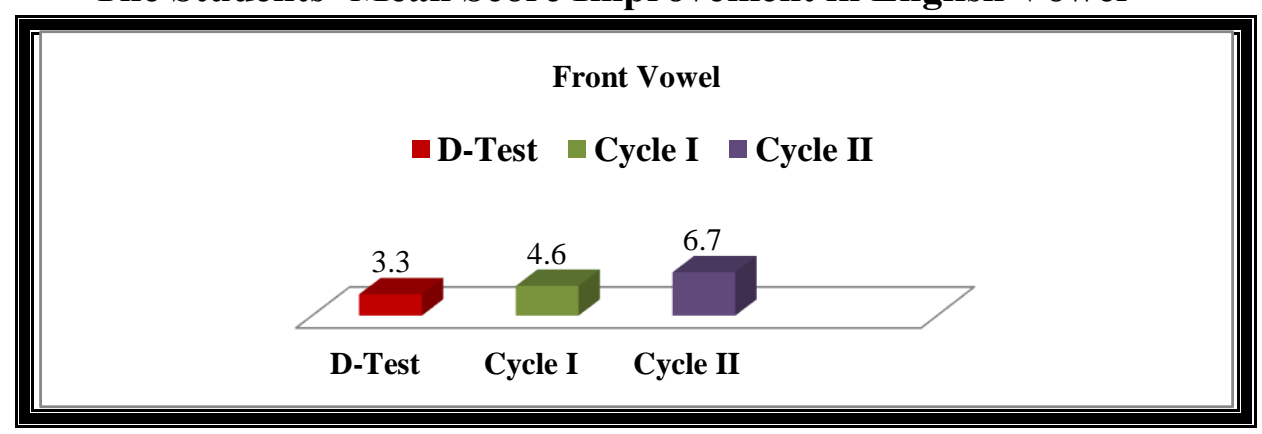

Graphic 6

The Students' Mean Score Improvement in English Vowel

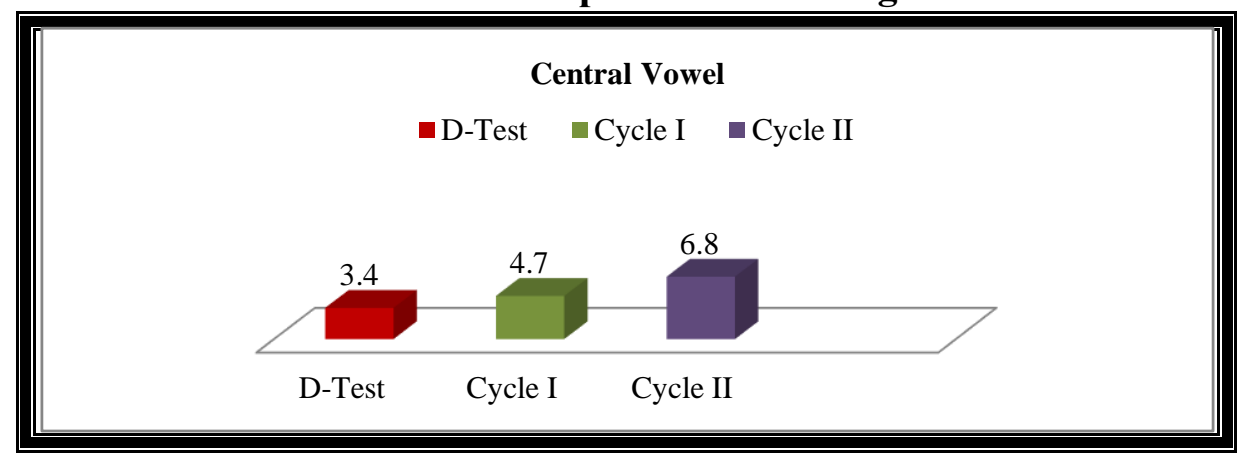

The graphic above shows the improvement of the students' pronunciation ability of English front vowel and English central vowel in cycle II are higher (6.7) and (6.8) than cycle I (4.6) and (4.7) and data source (D-Test) (3.3) and (3.4). It also shows that the result of data source is the lowest ability. After Implementing NRT (Noticing-Reformulation Task) in cycle I and cycle II, there is 
a significant improvement of the students' pronunciation ability of English front and central vowel.

\section{The Improvement of the Student's Pronunciation Ability}

The application of NRT (Noticing-Reformulation Task) in improving the students' pronunciation ability is dealing with consonant (CST) in fricative consonant (FC), affricative consonant (AC) and vowel (VWL) in front vowel (FV), central vowel (CV). The improvement of the students' ability that dealing with the English consonant of fricative and affricative can be seen clearly in the following table:

Table 3

The Improvement of the Student's Pronunciation Ability in Consonant

\begin{tabular}{|c|c|c|c|c|c|c|c|}
\hline & \multicolumn{5}{|c|}{$\begin{array}{l}\text { The Improvement of Students' Consonant (CST) } \\
\text { Pronunciation Ability }\end{array}$} & \multicolumn{2}{|c|}{ Improvement } \\
\hline & \multirow[t]{2}{*}{$\begin{array}{l}\text { Data Source } \\
\text { (D-Test) }\end{array}$} & \multicolumn{2}{|c|}{ Cycle I } & \multicolumn{2}{|c|}{ Cycle II } & \multirow{2}{*}{$\mathrm{DS} \rightarrow \mathrm{CI}$} & \multirow{2}{*}{$\mathrm{CH} \mathrm{CII}$} \\
\hline & & FC & $\mathbf{A C}$ & FC & $\mathbf{A C}$ & & \\
\hline$\sum X$ & $\begin{array}{c}\mathrm{FC}(83.2), \mathrm{AC} \\
(86.5)\end{array}$ & 119.2 & 118.2 & 179.5 & 186.6 & \multirow{4}{*}{$\begin{array}{l}\mathrm{FC} \\
(44.8 \%) \\
\mathrm{AC} \\
(40.0 \%) \\
\quad 40.0 \%\end{array}$} & \multirow{4}{*}{$\begin{array}{l}\mathrm{FC} \\
(52.3 \%) \\
\mathrm{AC} \\
(57.1 \%)\end{array}$} \\
\hline $\mathrm{N}$ & 28 & \multicolumn{2}{|c|}{28} & \multicolumn{2}{|c|}{28} & & \\
\hline $\bar{X}$ & $\mathrm{FC} \mathrm{(2.9),} \mathrm{AC} \mathrm{(3.0)}$ & 4.2 & 4.2 & 6.4 & 6.6 & & \\
\hline $\bar{X}$ & 3.0 & \multicolumn{2}{|c|}{4.2} & \multicolumn{2}{|c|}{6.5} & & \\
\hline
\end{tabular}

The table above shows that there is an improvement of the students' pronunciation ability from data Source (D-Test) to cycle I and cycle II, where in data source (D-Test) the students' mean score achievement in pronunciation ability is (2.9) and (3.0), but after evaluation in cycle I the students' pronunciation ability becomes (4.2) and also (4.2). Thus, the improvement of students' pronunciation ability achievement from data source (D-Test) to cycle I is $(44.8 \%)$ and $(40.0 \%)$. There is also a significant improvement of students' pronunciation ability from cycle I to cycle II where the students' pronunciation ability in cycle I is (4.2), (4.2) and in cycle II is (6.4), (6.6). Thus, the improvement of students' pronunciation ability achievement from cycle I to cycle II is $(52.3 \%)$ and $(57.1 \%)$

The table above also shows that there is a significant improvement of students' pronunciation ability after taking an action in cycle I and cycle II through the application of NRT (Noticing-Reformulation Task). 
To see clearly the improvement of the students' pronunciation ability, following graphic is presented:

Graphic 7

The Students' Improvement of Pronunciation Ability in Consonant

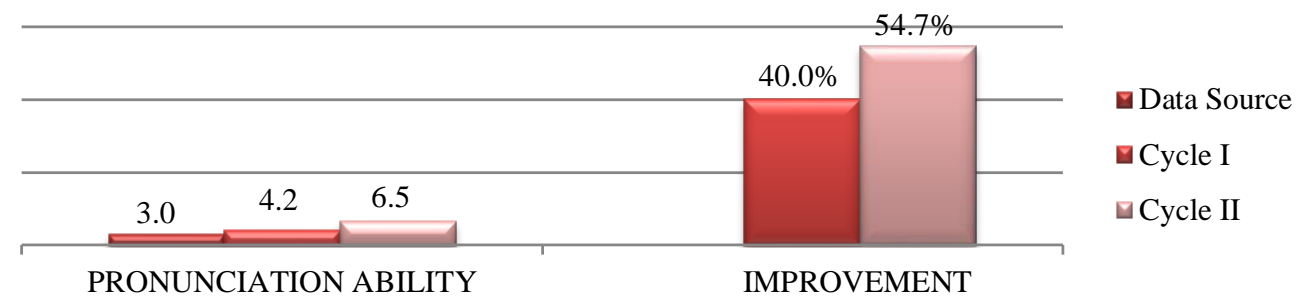

The graphic above shows the improvement of students' pronunciation ability in cycle II is higher (6.5) than cycle I (4.2) and data source (3.0). It also shows that the result of data source is the lowest achievement. After evaluating in cycle I and cycle II, there is a significant improvement of the students' pronunciation ability that shown clearly in the chart after taking an action in cycle through NRT (Noticing-Reformulation Task).

\section{Table 4}

The Improvement of the Student's Pronunciation Ability in Vowel

\begin{tabular}{|c|c|c|c|c|c|c|c|}
\hline & \multicolumn{5}{|c|}{ The Improvement of Students' Vowel (VWL) Pronunciation Ability } & \multicolumn{2}{|c|}{ Improvement } \\
\hline & \multirow[t]{2}{*}{$\begin{array}{c}\text { Data Source } \\
\text { (D-Test) }\end{array}$} & \multicolumn{2}{|c|}{ Cycle I } & \multicolumn{2}{|c|}{ Cycle II } & \multirow[t]{2}{*}{$\mathrm{DS} \rightarrow \mathrm{CI}$} & \multirow[t]{2}{*}{$\mathrm{C} \mapsto \mathrm{CII}$} \\
\hline & & FV & $\mathrm{CV}$ & FV & $\mathrm{CV}$ & & \\
\hline$\sum X$ & FV(94.3), CV (94.4) & 129.0 & 132.8 & 188.1 & 189.8 & & \\
\hline $\mathrm{N}$ & 28 & \multicolumn{2}{|c|}{28} & \multicolumn{2}{|c|}{28} & $\mathrm{FV}(39.3 \%)$ & FV $(45.6 \%)$ \\
\hline $\bar{X}$ & $\mathrm{FV}(3.3), \mathrm{CV}(3.4)$ & 4.6 & 4.7 & 6.7 & 6.8 & $\mathrm{CV}(38.2 \%)$ & CV $(44.6 \%)$ \\
\hline $\bar{X}$ & 3.3 & \multicolumn{2}{|c|}{4.6} & \multicolumn{2}{|c|}{6.7} & $39.3 \%$ & $45.6 \%$ \\
\hline
\end{tabular}

The table above shows that there is an improvement of the students' pronunciation ability from data Source (D-Test) to cycle I and cycle II, where in data source (D-Test) the students' mean score achievement in pronunciation ability is (3.3) and (3.4), but after evaluating in cycle I the students' pronunciation ability becomes (4.6) and also (4.7). Thus, the improvement of students' pronunciation ability achievement from data source (D-Test) to cycle I is $(39.3 \%)$ and $(38.2 \%)$. There is also a significant improvement of students' 
pronunciation ability from cycle I to cycle II where the students' pronunciation ability in cycle I is (4.6), (4.7) and in cycle II is (6.7), (6.8). Thus, the improvement of students' pronunciation ability achievement from cycle I to cycle II is $(45.6 \%)$ and $(44.6 \%)$

The table above also shows that there is a significant improvement of students' pronunciation ability after taking an action in cycle I and cycle II through the application of NRT (Noticing-Reformulation Task).

To see clearly the improvement of the students' pronunciation ability, following graphic is presented:

Graphic 8

The Students' Improvement in Pronunciation Ability in Vowel

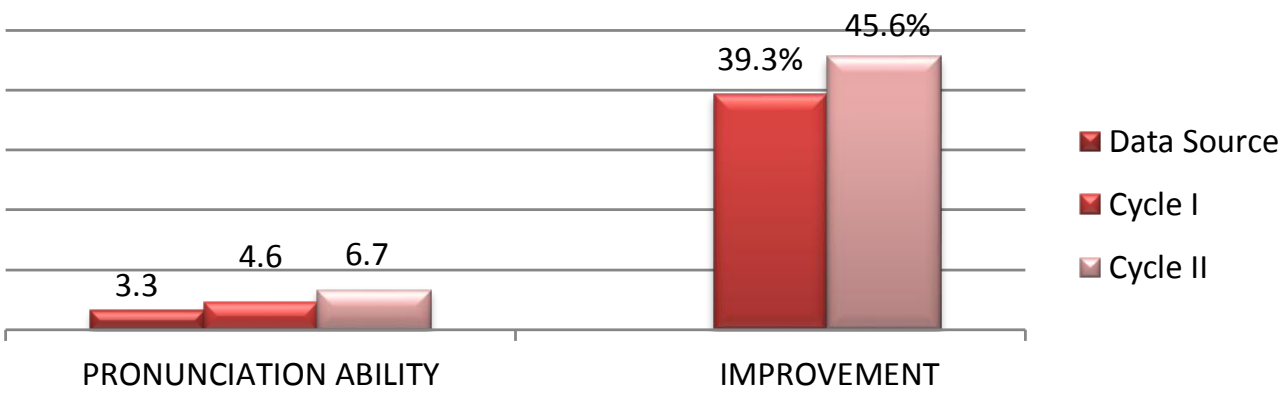

The graphic above shows the improvement of the students' pronunciation ability in cycle II is higher (6.7) than cycle I (4.6) and data source (3.3). It also shows that the result of data source is the lowest achievement. After evaluating in cycle I and cycle II, there is a significant improvement of the students' pronunciation ability that shown clearly in the chart after taking an action in cycle through NRT (Noticing-Reformulation Task).

\section{The Result of the Students' Activeness in Learning Process}

In this table showed the activeness of students' improvement in learning process after Implementing NRT (Noticing-Reformulation Task) as follows:

Table 9

Result of the students' activeness each meeting in cycle I and II

\begin{tabular}{|c|c|c|c|c|}
\hline \multirow{2}{*}{ Cycles } & \multicolumn{4}{|c|}{ Meeting } \\
\cline { 2 - 5 } & $1^{\text {st }}$ & $\begin{array}{c}2^{\text {nd }} \\
\%\end{array}$ & $\begin{array}{c}3^{\text {rd }} \\
\%\end{array}$ & $\begin{array}{c}4^{\text {th }} \\
\%\end{array}$ \\
\hline I & $41.9 \%$ & $49.1 \%$ & $51.7 \%$ & $58.0 \%$ \\
\hline II & $68.7 \%$ & $70.5 \%$ & $71.4 \%$ & $81.2 \%$ \\
\hline
\end{tabular}


The result of the table above is formulated based on the technique of data analysis and score of the students that are collected through observation sheet. The researcher can explain that the result of students' observation in learning process through NRT (Noticing-Reformulation Task) every meeting in cycle I is still low with percentage from the first meeting to the fourth meeting are (41.9\%), (49.1\%), (51.7\%), and (58.0\%). Percentage of the first meeting till the fourth meeting of the cycle II are (68.7\%), (70.5\%), (71.4\%), and (81.2\%). It means that there is an improvement that can be shown in students' observation process from cycle I to cycle I

\section{Graphic 9}

\section{Result of the students' activeness each meeting in cycle I and II}

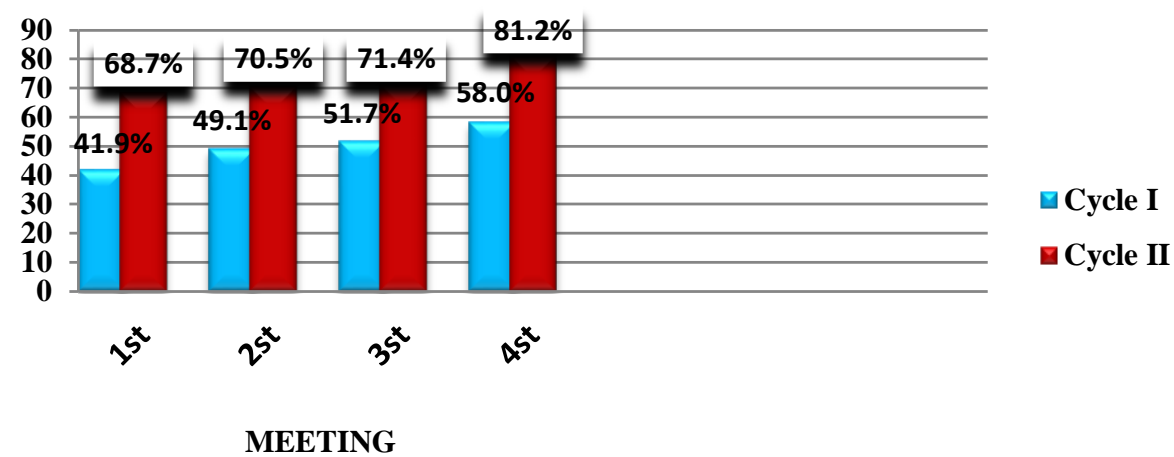

The graphic above shows the result of students' observation in learning pronunciation process through NRT (Noticing-Reformulation Task) by the students' of the eleventh grade of SMK Negeri 1 Jeneponto. This graphic presented the students' participation during teaching-learning process in pronouncing from cycle I to cycle II. From the graphic it's known that there is changing of students' participation in learning process from cycle I to cycle II. The students' participation in learning pronunciation in cycle I is low, percentage score from the first meeting to the fourth meeting are $(41.9 \%),(49.1 \%),(51.7 \%)$, and $(58.0 \%)$. While the percentages score from the first to the fourth meeting in cycle II are $(68.7 \%),(70.5 \%),(71.4 \%)$, and $(81.2 \%)$.

\section{B. Discussion}

\section{Result of the Students' Improvement in English Consonant}


Based on the data of the results of the observation indicated that cycle I some of the students know a little bit English fricative consonant, whereas there are 1 student (3.5\%) got good, 18 students $(64.2 \%)$ got poor, although 9 students $(32.1 \%)$ got very poor, with the mean score (4.2). The researcher needed to do stabilization in the second cycle especially the students' English fricative consonant ability. Next, in cycle II it can be improved until there are 2 students (7.1\%) got very good, 8 students $(28.5 \%)$ got good, 15 student $(53.5 \%)$ got fair, a little bit lower than cycle I for poor category got 3 students $(10.7 \%)$ and there is no more students got very poor as like in cycle I with the mean score (6.4).

In the first cycle, the English consonant of fricative was not too bad than the other indicators like as the indicator of English front vowel. The result can be seen after testing and observing (pronunciation test of the first cycle), whereas the number of students in poor score was sixty four point two percent although some of the students are lack of English fricative consonant but this item made the researcher are happy although there was still aspect need to be improved in the next cycle.

After testing and observing in the second cycle, the indicator of English fricative consonant really has a good improvement. In this section almost the students could read the text and pronounce the words with the good pronunciation whereas just views of students are poor of fricative consonant (pronunciation test of the second cycle).

The other sides, based on the data of the results of the observation indicated that cycle I some of the students still lack in English affricative consonant, whereas there are 2 students $(7.1 \%)$ got good, 3 students $(10.7 \%)$ got fair, 10 students $(35.7 \%)$ got poor although 13 students $(46.4 \%)$ got very poor, with the mean score (4.2). The researcher needed to do stabilization in the second cycle especially the students' pronunciation ability of English affricative consonant. Next, in cycle II it can be improved until there are 2 students $(7.1 \%)$ got very good, 15 students (53.5\%) got good, 11 students (39.2\%) got fair, and there is no students got poor and very poor as like in cycle I with the mean score (6.6).

The pronunciation ability of English affricative consonant means that how the students pronounce/read the text and words correctly in pronouncing/reading, 
after testing and observing at the first cycle, students showed that almost of all students were lacks of the way of pronouncing the affricative words/text even in fricative case; the causes were students never study intensively about how to read the text in English well and correctly. Because of this problem, in the second cycle the researcher tried to explain more about how to read/pronounce the text well and correctly and the result showed that there was improvement of pronunciation than the first cycle, whereas the number of students' frequency at the first cycle differs from the second cycle (pronunciation test in reading spot).

\section{Result of the Students' Improvement in English vowel}

Based on the data of the results of the observation indicated that cycle I some of the students still lack in English front vowel, whereas there are 3 students (10.7\%) got good, 2 students (7.1\%) got fair, although 23 students $(82.1 \%)$ got poor, with the mean score (4.6). The researcher needed to do stabilization in the second cycle especially the students' pronunciation ability of English front vowel. Next, in cycle II it can be improved until there are 2 students $(7.1 \%)$ got very good, 12 students (42.8\%) got good, 14 students (50.0\%) got fair, and there is no students got poor as like in cycle I with the mean score (6.7).

The another case, the data of the results of the observation also indicated that cycle I some of the students were still lack of English central vowel, in which there are 3 students (10.7\%) got good, 4 students (14.2\%) got fair, 16 students $(57.1 \%)$ got poor, although 5 students $(17.8 \%)$ got very poor, with the mean score (4.7). The researcher needed to do stabilization in the second cycle especially the students' pronunciation ability of English central vowel. Next, in cycle II it can be improved until there are 4 students (14.2\%) got very good, 11 students (39.2.\%) good, 13 students (46.4\%) got fair, and there is no students got poor and very poor as like in cycle I with the mean score (6.8).

Students' English vowel (front and central vowel) in first cycle was very lack, whereas just twenty one point four percent of students got good score and other was fair, poor and very poor, the causes were the students' habit of reading/pronouncing the text or word based on the writing or spelling is, (pronunciation test in reading spot of the first cycle). Because of this problem made the researcher worked hard in the second cycle to solve it. In the second 
cycle after testing and observing the result also showed that there was a maximal improvement than the first cycle. The indicator of English affricative consonant was maximal because the researcher and collaborator gave maximal chance to the students to try harder in pronouncing/reading the text or word well and correctly (pronunciation test of second cycle).

\section{The Improvement of the Student's Pronunciation Ability}

The data above indicates that there is improvement of the students' pronunciation ability from data Source (D-Test) to cycle I and cycle I to cycle II, where in Data-Source (D-Test) the students' mean score achievement in pronunciation ability of English consonant is (5.9), but after evaluation in cycle I the students' pronunciation ability becomes (8.4). Thus, the improvement of students' pronunciation ability achievement from data source (D-Test) to cycle I is $(40.0 \%)$. There is also a significant improvement of students' pronunciation ability from cycle I to cycle II where the students' pronunciation ability in cycle I is (4.2) and in cycle II is (6.5). Thus, the improvement of students' pronunciation ability achievement from cycle I to cycle II is (54.7\%), whereas Data-Source (DTest) the students' mean score achievement in pronunciation ability of English vowel is (6.7), but after evaluating in cycle I the students' pronunciation ability becomes (9.3). Thus, the improvement of students' pronunciation ability achievement from data source (D-Test) to cycle $\mathrm{I}$ is $(39.3 \%)$. There is also a significant improvement of students' pronunciation ability from cycle I to cycle II where the students' pronunciation ability in cycle I is (4.6) and in cycle II is (6.7). Thus, the improvement of students' pronunciation ability achievement from cycle I to cycle II is (45.6\%).It also shows that the result of data source is the lowest achievement. After evaluation in cycle I and cycle II, there is a significant improvement of the students' pronunciation ability that shown clearly in the chart after taking an action in cycle II through NRT (Noticing-Reformulation Task).

\section{The Result of the Students' Activeness in Learning Process}

Based on the data analysis as result of observation sheet of students' participation in learning process in previous findings shows that the participation of students in cycle I from the first meeting to the fourth meeting are $41.9 \%$, $49.1 \%, 51.7 \%$, and $58.0 \%$. Percentages of the first till the fourth meeting of the 
cycle II were $68.7 \%, 70.5 \%, 71.4 \%$, and $81.2 \%$. From the data analysis shows that the students' participation in cycle I in process learning is still low. So that's why the researcher did repairing in cycle II so that there was significant improvement in cycle II of students' participation.

Basically cycle II had positive effect on the students' pronunciation because in NRT (Noticing-Reformulation Task) the researcher gave opportunity to students to express their strength to conduct the activity in the class and the students can learn English especially English pronunciation without being aware they are studying, thus without stress, they can learn a lot. However, NRT (Noticing-Reformulation Task) is a good way that can be used in improving the students' pronunciation ability.

\section{CONCLUSION AND SUGGESTION}

\section{A. Conclusion}

Using NRT (Noticing-Reformulation Task) was able to improve the students' pronunciation ability of English consonant at the Eleventh Grade of Accounting Unggulan of of SMK Negeri 1 Jeneponto. It is proved by the students' achievement in cycle II is higher than cycle I and D-Score where in DScore the students' mean score achievement in English fricative and affricative are 2.9 and 3.0, but after evaluation in cycle I the students' pronunciation ability of English fricative and affricative consonant become 4.2 and 4.2 whereas in cycle II 6.4 and 6.6. Furthermore, using NRT (Noticing-Reformulation Task) was able to improve the students' pronunciation ability of English vowel at the eleventh Grade in Accounting Unggulan of SMK Negeri 1 Jeneponto. It is proved by the students' achievement in cycle II is higher than cycle I and D-Score where in DScore the students' mean score achievement in English front and central vowel are 3.3 and 3.4, but after evaluation in cycle I the students' pronunciation ability of English front and central vowel become 4.6 and 4.7 and cycle II 6.7 and 6.8 . Apart from this, NRT (Noticing-Reformulation Task) was able to make the students were active in learning process, especially in pronunciation spot. 


\section{B. Suggestion}

To improve the pronunciation ability command of the students, the writer suggested to English teacher to provide students with more pronunciation exercises in the classroom, thus, the students get enough time for practicing and applying this NRT (Noticing-Reformulation Task) as one of alternative in teaching and learning process, mainly in pronunciation aspect.

\section{REFERENCES}

Ampa, Andi, tenri. 2008. New Horizons in English Pronunciation. Makassar: Makassar Muhammadiyah University

Ampa, Andi, Tenri. 2010. English Phonology. Makassar: English Education DepartmentMakassar Muhammadiyah University

Badulu, Muis. 2004. Introduction to Linguistic.FBS UNM. Makassar.

Brown, G. and Yule, G. 1983. Teaching the Spoken Language. Cambridge, England: Cambridge University Press.

Byrne, Donn, 1981. Teaching English through English. London: Longman Ltd.

Crystal, D. A Dictionary of Linguistics and Phonetics. BTS. Britain.

Gilbert. B, Judy. 2008. Teaching Pronunciation Using the Prosody Pyramid. Cambridge: University Press

Harmer, James. 1991. Practice of English Language Teaching. Pocket Dictionary Oxford.

Hornby, As, ApCowie, and AC. Gimson. 1986. Oxford Advanced Learner's Dictionary. London: Oxford University Press.

Jackson, Wowand. 1986. Analyzing English an Introduction to Description Linguistics. New York: Pergamon Press, inc.

Nunan, David. 2004. Task Based Language Teaching. Cambridge: University Press

Orion. G. F. 1987. Pronouncing American English. Boston: Heinle and Heinle Publisher

Oxford Dictionary. 1991. Oxford Learners Pocket Dictionary. Oxford University Press. Walton Street, New York 
Roach, Peter. 1987. English Phonetics and Phonology. Cambridge University Press, Cambridge.

Smith, Joanna and Beckmann, Basheba (2005). Improving Pronunciation through Noticing-Reformulation Task.Unitec New Zealand

Thornbury (2007). Improving Pronunciation through Noticing-Reformulation Task.Unitec New Zealand

Thornbury, S. 1997. Reformulation and Reconstruction: Task That Promote 'Noticing' in ELT Journal Volume 51/4 October. Oxford: University Press

Thornbury, S. 2005. How to teach speaking. Harlow, England: Longman

Webster's. 1996. Third New International Dictionary. A.B. Dartmouth College; A.M, Harrad University; Ph.d, Columbia University

Hay, C, J. 1970. Teaching of Pronunciation a classroom. Guide London Longman.

Echols, John M., and Hassan Shadily. 2003. Kamus Indonesia Inggris . PT. Gramedia. Jakarta. 